\title{
Galactorrhoea amenorrhoea syndrome due to internal carotid artery aneurysm
}

\author{
S.K. Garg and R.J. Dash
}

Department of Endocrinology, Postgraduate Institute of Medical Education and Research,Chandigarh-160012, India

\begin{abstract}
Summary: A 32 year old female with hyperprolactinaemia-galactorrhoea- amenorrhoea due to a right internal carotid artery aneurysm just before its bifurcation is described. She had two episodes of subarachnoid haemorrhage necessitating an emergency internal carotid artery ligation. She responded to bromocriptine treatment with restoration of her menses, normalization of circulating prolactin and disappearance of galactorrhoea.
\end{abstract}

\section{Introduction}

Since the report by Chiari, over a century ago, galactorrhoea has been reported to occur with a variety of endocrine and nonendocrine disorders (Sharp, 1935; Kleinberg et al., 1977). Subsequently, the development of a sensitive bioassay (Frantz \& Kleinberg, 1970; Kleinberg \& Frantz, 1971) and that of a radioimmunoassay for human prolactin (PRL) (Hwang et al., 1971; Frantz et al., 1972) have improved our understanding of hyperprolactinaemia with or without galactorrhoea. Prolactin secreting pituitary adenomas account for most (40-50\%) of such patients (L'Hermite et al., 1977). Hypothalamic and pituitary stalk lesions including sarcoidosis, tuberculosis, radiation damage, head trauma, and Hand Schullar-Christian disease also give rise to galactorrhoea-amenorrhoea syndrome (Finn \& Mount, 1971). We know of no report of galactorrhoea-amenorrhoea syndrome due to internal carotid artery aneurysm, and now describe one such patient.

\section{Case report}

A previously healthy, 32 year old woman was referred for evaluation of galactorrhoea. Six months before the detection of galactorrhoea, she was admitted with a history of headache and unconsciousness for $48 \mathrm{~h}$. Seven days later she had a fresh subarachnoid leak. Right carotid angiogram revealed a large internal carotid artery aneurysm arising just before its bifurcation (Figure 1). In view of her rapidly deteriorating neurological status and the development of con-

Correspondence: Prof. R.J. Dash, M.D., D.M.

Accepted: 12 December 1984 secutive right optic atrophy, right internal carotid artery ligation was performed. In the following 4 months she became conscious of galactorrhoea and on questioning admitted to amenorrhoea for 10 months. Menarchae was at 14 years of age. She had two uncomplicated normal deliveries in 1970 and in 1974. Spontaneous menstrual cycles occurred 6 months after her last baby whom she had breastfed for 9 months. She denied any self medication except for aspirin and was not on oral or injectable contraceptives. General physical examination was normal except for bilateral spontaneous galactorrhoea. Fundus revealed right optic atrophy. There was no neurological deficit. Systemic and pelvic examinations were normal.

\section{Investigations}

Routine haematology and biochemistry, and X-rays of the skull, with a coned down view of the sella, were normal. Right common carotid angiogram revealed a large internal carotid artery aneurysm arising just before its bifurcation (Figure 1). Computerized tomographic (CT) scan of the brain did not show any pituitary lesion (Figure 2) but revealed a localized suprasellar contrast enhancement suggestive of an aneurysm (Figure 3). Basal serum prolactin (PRL) was in the range of 2,300-3,300 IU/1 (normal $78-600 \mathrm{mIU} / \mathrm{l}$ ) with a two-fold rise at $30 \mathrm{~min}$ $(5,000 \mathrm{mIU} / \mathrm{l})$ following thyrotrophin-releasing hormone (TRH; $100 \mu \mathrm{g}$ ) bolus stimulation. In response to L-dopa ( $0.5 \mathrm{~g}$ orally), the circulating PRL fell to $890 \mathrm{mIU} / 1$. Other circulating hormone levels were as follows: $\mathrm{LH}$ - 1.2, $2.1 \mathrm{IU} / 1$ (normal < $15 \mathrm{IU} / \mathrm{l}$ ), FSH 1.1, 1.3 (normal <15 IU $/ \mathrm{ml}$ ), Oestradiol-17 $\beta-180$, $295 \mathrm{pmol} / \mathrm{l}$ (normal 600-1500 pmol/1), progesterone - 

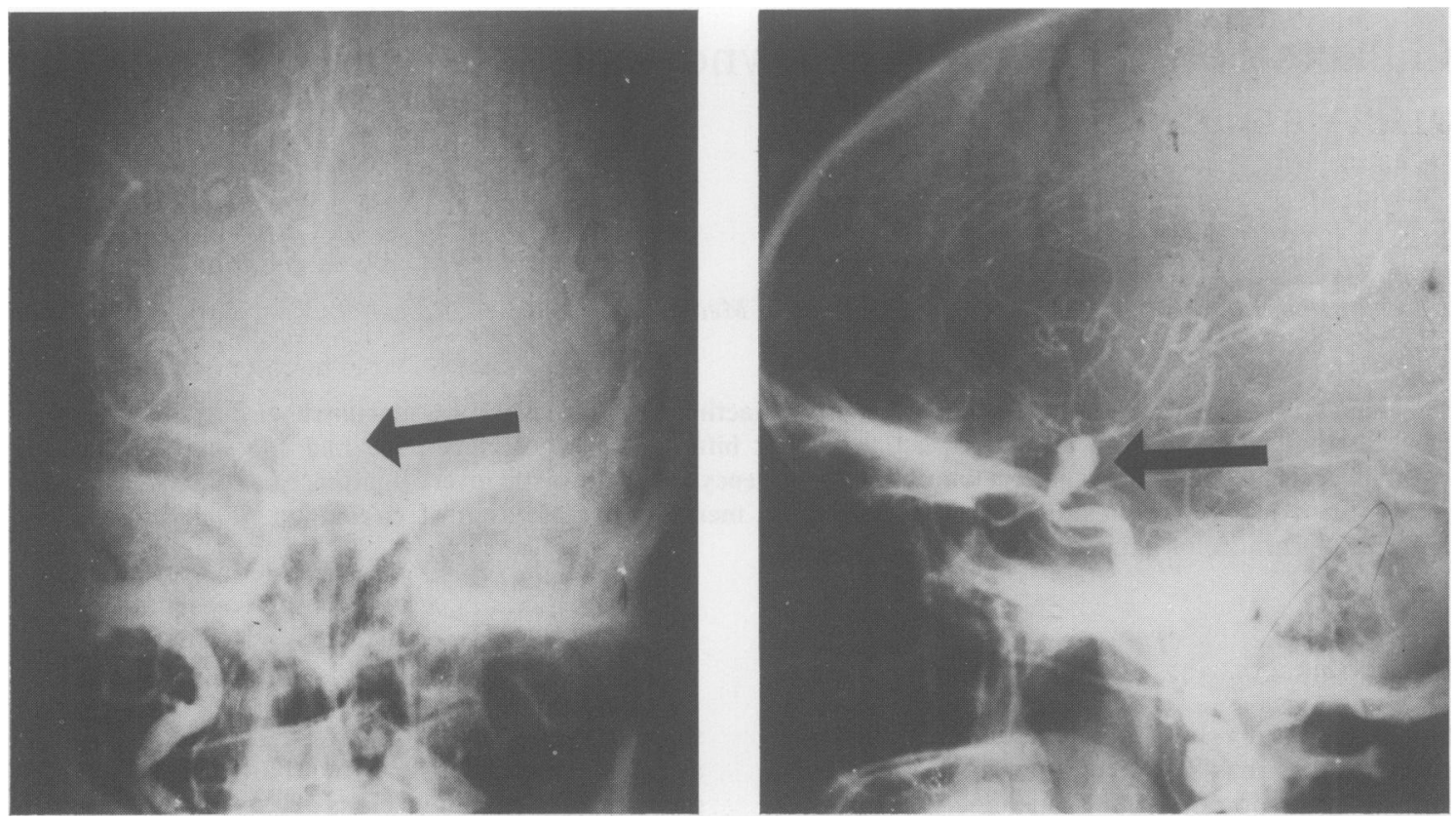

Figure 1 Carotid angiogram showing a right internal carotid artery aneurysm at the bifurcation (arrow). Note also normal size of the sella turcica.

$1.4,2.8 \mathrm{nmol} / 1$ (normal $3-60 \mathrm{nmol} / 1), \mathrm{T} 3-0.98 \mathrm{ng} / \mathrm{ml}$ (normal $0.8-1.6 \mathrm{ng} / \mathrm{ml}) \mathrm{T} 4-110 \mathrm{ng} / \mathrm{ml}$ (normal 60$120 \mathrm{ng} / \mathrm{ml}$ ), TSH $2.1 \mathrm{U} / \mathrm{ml}$ (normal $<5 \mathrm{U} / \mathrm{ml}$ ), cortisol

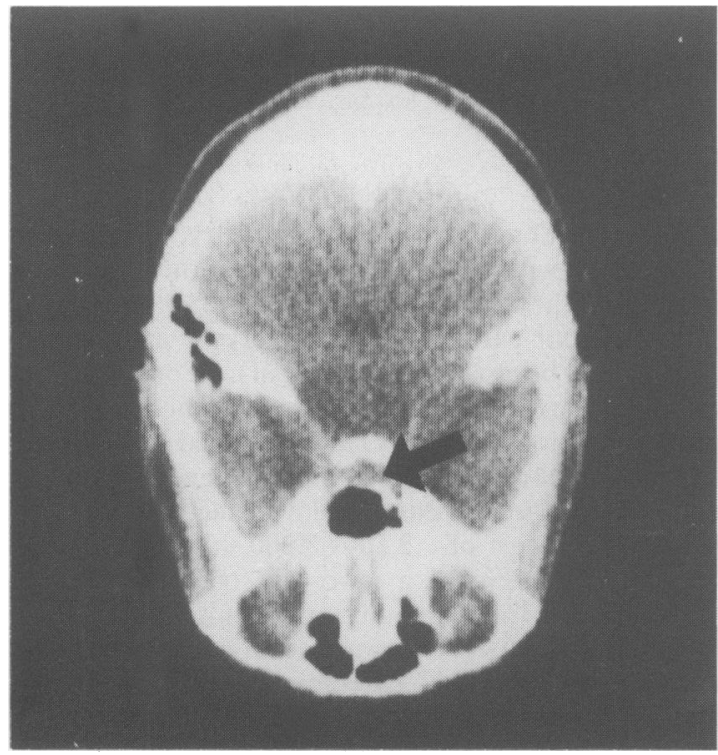

Figure 2 CT scan showing the normal sellar outline and its contents.
$-0800 \mathrm{~h} 490 \mathrm{nmol} / 1$ (normal $400-690 \mathrm{nmol} / \mathrm{l}$ ), cortisol $1800 \mathrm{~h}-320 \mathrm{nmol} / 1$ (normal $200-400 \mathrm{nmol} / \mathrm{l}$ ).

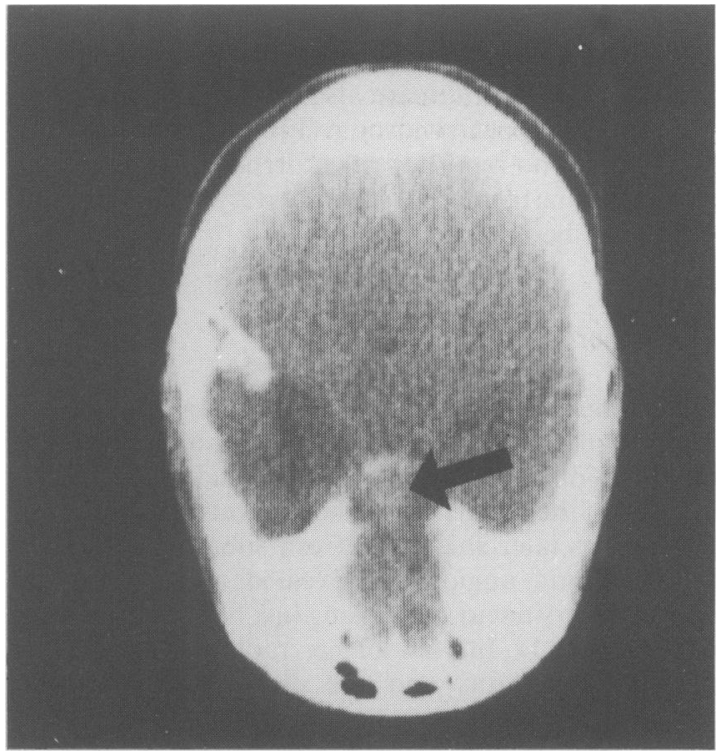

Figure 3 CT scan showing a localized suprasellar contrast enhancement suggestive of aneurysm. 


\section{Course in the following 18 months}

She was treated with bromocriptine (Parlodel, Sandoz Pharmaceuticals), initially $2.5 \mathrm{mg} / \mathrm{d}$ at night, gradually increased to $10 \mathrm{mg} / \mathrm{d}$ in three divided doses. Galactorrhoea disappeared completely after 6 weeks of therapy. She had spontaneous menses after 10 weeks of treatment and thereafter they occurred regularly. Her basal prolactin gradually decreased to $640 \mathrm{IU} / 1$. After 6 months of bromocriptine $10 \mathrm{mg} /$ day, the dose was gradually lowered to $2.5 \mathrm{mg}$ a.m. and $1.25 \mathrm{mg} \mathrm{p.m}$. and on this she remained free of galactorrhoea, continued to have normal menses and normal circulating PRL. The patient refused surgery on the carotid aneurysm.

\section{Discussion}

The cause of galactorrhoea, with or without amenorrhea, is not identifiable in a large number of patients (Kleinberg et al., 1977). This case highlights one such instance. The long list of causes of galactorrhoea (Finn

\section{References}

BOWERS, C.Y., FRIESEN, H.G. \& FOKLERS, K. (1973). Further evidence that TRH is also a physiological regulatory of PRL secretion in man. Biochemical and Biophysical Research Communications, 51, 512.

EHNI, G. \& ECKLES, N.E. (1959). Interruption of the pituitary stalk in the patient with mammary cancer. Journal of Neurosurgery, 16, 628.

FINN, J.E. \& MOUNT, L.A. (1971). Galactorrhoea in males with tumors in the region of the pituitary gland. Journal of Neurosurgery, 35, 723.

FRANTZ, A.G., KLEINBERG, D.L., NOEL, G.L. (1972). Studies on prolactin in man. Recent Progress in Hormone Research, 28, 527.

FRANTZ, A.G. \& KLEINBERG, D.L. (1970). Prolactin: evidence that it is separate in plasma by in vitro bioassay. Journal of Clinical Investigation, 50, 557.

HAUN, C.K. \& SAWYER, C.H. (1961). The role of the hypothalamus in initiation of milk secretion. Acta Endocrinologica, 38, 99.

HWANG, P., GUYDA, H. \& FRIESEN, H. (1971). A radioimmunoassay for human prolactin. Proceedings of the National Academy of Sciences of the United States of America, 68, 1902.
\& Mount, 1971) includes hypothalamic infarction, encephalitis, syringomyelia and pituitary stalk section. Pituitary prolactin secretion is enhanced by lesions in the arcuate and ventromedial nuclei of the hypothalamus (Haun \& Sawyer, 1961) and by hypophyseal stalk section (Ehni \& Eckles, 1959). In this patient the aneurysm of the internal carotid artery at the bifurcation is strategically located to interfere with prolactin inhibitory factor (PIF) secretion and thus induce hyperprolactinaemia and lead to galactorrhoea-amenorrhoea. Existence of a pituitary microadenoma is unlikely because of a normal CT scan. Moderately elevated basal prolactin and its doubling by TRH bolus stimulation also supports the diagnosis of pathological hyperprolactinaemia due to causes other than pituitary microadenoma (Kleinberg et al., 1977; Bowers et al., 1973). Consequent to hyperprolactinaemia, she had hypoestrogen state and anovulation as indicated by low circulating progesterone. Data on other hormones were essentially normal and excluded any significant alterations in other pituitary thyroid and adrenocortical functions.

JEWELWICZ, R. (1975). Management of infertility resulting from anovulation. American Journal of Obstetrics and Gynecology, 122, 909.

KAUL, K. \& DASH, P.J. (1979). Prolactin II. Journal of the Association of Physicians of India, 27, 975.

KLEINBERG, D.L. \& FRANTZ, A.G. (1971). Human prolactin: measurement in plasma by in vitro bio assay. Journal of Clinical Investigations, 50, 1557.

KLEINBERG, D.L., NOEL, G.L. \& FRANTZ, A.G. (1977). Galactorrhoea: a study of 235 cases, including 48 with pituitary tumors. New England Journal of Medicine, 296, 589.

L'HERMITE, C.M., VEKEMANS, A., DANAYER, P. \& ROBYN, C. (1977). Pharmacological and pathological aspects of human PRL secretion. Progress in Reproductive Biology, 2 , 244.

MCNATTY, K.P., SAWERS, R.S. \& MCNELLY, A.S. (1974). A possible role for PRL in control of steroid section by human graffian follicle. Nature, 250, 633.

SHARP, E.A. (1935). Historical review of a syndrome embracing utero-ovarian atrophy with persistent lactation (Frommel's disease), American Journal of Obstetrics and Gynecology, 30, 411. 